\title{
Fire and distance from unburned forest influence bird assemblages in Southern Andean Yungas of Northwest Argentina: a case study
}

Adriana Marisel Morales ${ }^{1} \mathbb{D}$, Natalia Politi ${ }^{*}$, Luis Osvaldo Rivera', Constanza Guadalupe Vivanco ${ }^{1}$ and Guillermo Emilio Defossé ${ }^{2}$

\begin{abstract}
Background: Wildfires affect vegetation structure, functions, and other attributes of forest ecosystems. Among these attributes, bird assemblages may be influenced by the distance from undisturbed to fire-disturbed forests. Information about this influence is essential for designing management plans aimed at conserving birds' diversity in undisturbed forests, which contributes to their sustainability. In Northwest Argentina, timber extraction and mancaused fires threaten the sustainability of Southern Andean Yungas forests. In this region, we evaluated, in relation to a reference unburned forest, the effects of close and distant fire-disturbed patches on bird assemblages, exploring also relationships between burned and unburned forest structures on bird assemblages. On each site, we determined forest structural variables, and twice per year, from 2015 to 2017, we recorded birds seen or heard on every site, from dawn to 1000 hours, at 300.5 ha counting points.

Results: Abundance and richness of bird species were lower in the unburned reference site than in close- and distant-burned sites; the farther the distance of burned sites to the unburned site, the less similarity in bird assemblages. Bird assemblage abundance appeared to be associated with snag height and basal area. However, bird species in mature forests were present at all sites and outnumbered those typically found in forest edges, or secondary or disturbed forests.

Conclusions: Connected areas between unburned and burned forest patches provide habitat for birds living in both environments. Preventing forest fragmentation by reducing the number and size of wildfires, promoting selective timber logging, and banning post-fire snag removal will help promote suitable habitat for different bird assemblages and contribute to Yungas forests' sustainability. This study is the first step toward understanding how fire-patch distances to unburned forests may affect bird assemblages in subtropical Southern Andean Yungas forests in South America and provide a basis for comparison with other subtropical ecosystems around the world.
\end{abstract}

Keywords: climate change, connectivity, fire ecology, forest management, neotropic, piedmont forests

\footnotetext{
*Correspondence: npoliti@conicet.gov.ar

'Instituto de Ecorregiones Andinas, Universidad Nacional de Jujuy - Consejo Nacional de Investigaciones Científicas y Técnicas, Alberdi 47, 4600 San

Salvador de Jujuy, Jujuy, Argentina

Full list of author information is available at the end of the article
}

\section{Springer Open}

( ) The Author(s). 2020 Open Access This article is licensed under a Creative Commons Attribution 4.0 International License, which permits use, sharing, adaptation, distribution and reproduction in any medium or format, as long as you give appropriate credit to the original author(s) and the source, provide a link to the Creative Commons licence, and indicate if changes were made. The images or other third party material in this article are included in the article's Creative Commons licence, unless indicated otherwise in a credit line to the material. If material is not included in the article's Creative Commons licence and your intended use is not permitted by statutory regulation or exceeds the permitted use, you will need to obtain permission directly from the copyright holder. To view a copy of this licence, visit http://creativecommons.org/licenses/by/4.0/. 


\section{Resumen}

Antecedentes: Los incendios afectan la estructura de la vegetación, las funciones, y otros atributos de los ecosistemas forestales. Entre esos atributos, los ensambles de aves pueden estar influenciados por la distancia entre bosques no quemados y quemados. La información sobre esta influencia es esencial para diseñar planes de manejo orientados a conservar la diversidad de aves en bosques no quemados y que contribuyan a su sustentabilidad. En el noroeste de Argentina, la extracción de madera y los incendios antropogénicos amenazan la sustentabilidad de los bosques de las Yungas Australes. En esta región evaluamos, en relación a un bosque de referencia no quemado, los efectos de parches quemados cercanos y alejados sobre el ensamble de aves, explorando también las relaciones entre las estructuras del bosque quemado y no quemado y el ensamble de aves. En cada sitio determinamos las variables estructurales y dos veces al año, desde 2015 a 2017, registramos las aves vistas u oídas en cada sitio, desde el amanecer hasta las 1000 horas, en 30 puntos de 0,5 ha cada uno.

Resultados: La abundancia y riqueza de especies de aves fue menor en el sitio de referencia (no quemado) que en los sitios quemados cercanos y alejados. A mayor distancia entre el no quemado y los sitios quemados, se encontró menor similitud en los ensambles de aves. La abundancia de los ensambles de aves parece estar asociada con la altura y área basal de árboles muertos en pie. Sin embargo, las especies de aves típicas de bosques maduros estuvieron presentes en todos los sitios y sobrepasaron en número a aquellas encontradas típicamente en los bordes del bosque, o en bosques secundarios o disturbados.

Conclusiones: Las áreas conexas entre bosques no quemados y parches de bosques quemados proveen de hábitat para aves que viven en ambos ambientes. El prevenir la fragmentación de bosques mediante la reducción del número y tamaño de los incendios, la promoción de cortas selectivas, y la prohibición de remover árboles muertos en pie, va a ayudar a promover hábitats adecuados para diferentes ensambles de aves y contribuir así a la sustentabilidad de los bosques de las Yungas. Este estudio es un primer paso hacia el entendimiento de cómo la distancia entre parches de bosques quemados con no quemados puede afectar los ensambles de aves en los bosques subtropicales de las Yungas Australes de América del Sur y pude proveer de base para comparación con otros ecosistemas tropicales alrededor del mundo.

\section{Abbreviations}

AM: birds of disturbed environments

BBS: birds associated with forest edges or secondary environments

BM: birds that inhabit the interior of mature forests

CCA: Canonic Correspondence Analysis

$\mathrm{dbh}$ : diameter at breast height

GLM: General Linear Models

NMDS: Nonmetric MultiDimensional Scaling

PERMANOVA: PERmutational Multivariate ANalysis Of VAriance

QC: close-burned site

QL: distant-burned site

R: unburned forest site

\section{Introduction}

Wildfires are frequent disturbances that help maintain the structure and function of many forest ecosystems (Agee 1993), playing a key role in establishing and preserving habitat for several plant and animal species (Fontaine et al. 2009). However, fires occurring in forests not adapted to fire, or outside of their historical fire frequency range, may produce changes in forest structure and create a post-fire environment that could negatively affect forest biodiversity (Sodhi et al. 2011). Fires usually increase heterogeneity at landscape level, although they may simplify forest structures if stand scales are considered (Ponce Calderón et al. 2012). Bird assemblages constitute ideal groups for studying the effects of fire disturbances, mainly because they rapidly respond to changes in vegetation structure (Fontaine et al. 2009). After a wildfire, bird species inhabiting or depending on mature forests could be replaced by other species whose habitat is linked to forest edges, or by those living in secondary forests affected by fires or other disturbances (Sodhi et al. 2011). The effects of forest fires on bird assemblages have been studied exhaustively in temperate regions, but in subtropical regions of southern South America, these kinds of studies are still scarce (Sodhi et al. 2011).

The proximity, or distance between, burned and unburned forest patches may influence post-fire bird assemblages (Sodhi et al. 2011; Watson et al. 2012). Unburned forests act as a refuge and habitat for many bird species during a fire, and may facilitate recolonization of fire-affected forests (Watson et al. 2012). Some bird species respond in specific ways to forest fires, and these responses could be dependent upon the distance between burned and unburned forest patches (Law et al. 2018). 
The piedmont forest of the Southern Andean Yungas (i.e., the mountain forest of northern Argentina and southern Bolivia) is one of the most threatened ecosystems of the Neotropic ecozone, presumably because of uncontrolled human-caused fires and unsustainable logging (Brown et al. 2009; Martinuzzi et al. 2017). However, little is known about the fire ecology of these piedmont forests. Knowledge of fire effects on bird assemblages, including consideration of the distance between fire-affected and unaffected forests, will be crucial for designing long-term conservation strategies for maintaining bird biodiversity at landscape scale. The understanding of fire ecology in this ecosystem is very important, since predictions for climatic change in the region foresee increases in mean temperatures that could, in turn, increase fire occurrence and effects (Scholze et al. 2006; Flannigan et al. 2009). Under this scenario, remnant undisturbed forests could be key to helping preserve biodiversity in the region and to designing appropriate conservation strategies (Mayhew et al. 2019). These strategies will help assure a continuous provision of ecosystem services in a changing climate. The objective of this study was to evaluate how the distance between burned and unburned forest patches influences bird assemblages in the piedmont forest of the Southern Andean Yungas in Northwest Argentina. This objective was achieved by: (1) determining and comparing the bird assemblages in fire-disturbed forest patches in relation to the distance to a reference unburned forest; (2) surveying and comparing structural forest variables among burned and reference unburned sites; and (3) exploring relationships between bird assemblages and forest structures in burned and unburned forest sites.

\section{Methods}

\section{Study area}

The Southern Andean Yungas is a tropical and subtropical moist broadleaf forest ecoregion stretching from southern Bolivia to northwestern Argentina (Cabrera and Willink 1973; Cabrera 1994; Oyarzabal et al. 2018). The Southern Andean Yungas possess an important conservation value because of their high biodiversity, which includes several endemic and threatened species (Pidgeon et al. 2015). The lower elevation zone (i.e., 400 to 900 m.a.s.l.) of the Southern Andean Yungas ecoregion constitutes the so-called "piedmont forest" and is part of the neotropical seasonal dry forests (Prado et al. 2000). This piedmont forest shows a monsoonal rainfall regime with a marked seasonality (rainy season from October to March and dry season from April to September). Annual precipitation varies from 800 to $1000 \mathrm{~mm}$ (Brown et al. 2009), and mean annual temperature is $21.1{ }^{\circ} \mathrm{C}$ (Arias and Bianchi 1996). The most characteristic tree species of this piedmont forest are Calycophyllum multiflorum Griseb., Phyllostylon rhamnoides Taub., Handroanthus impetiginosus Mattos., Anadenanthera colubrina Griseb., Myroxylon peruiferum L. f., Cordia trichotoma Steud., Cordia americana Gottschling \& Mill., Cedrela angustifolia DC., Enterolobium contortisiliquum Morong, and Myracrodruon urundeuva Allemão (Lomáscolo et al. 2010). More than $90 \%$ of the area of this forest in Argentina had been disturbed by anthropogenic activities (agriculture, logging, cattle grazing, and fires), while some relatively small undisturbed stands remained in the northwestern provinces of Salta and Jujuy (Brown et al. 2009). Some remnant stands of the piedmont forest, however, are severely threatened by arson fires, especially during the dry season, when about $70 \%$ of the trees lose their foliage (Brown and Malizia 2004).

This study was carried out at the piedmont Southern Andean Yungas forest, Jujuy province, Argentina. We selected three stands considered representative of burned and unburned forests. The first stand was selected on the basis of having a good conservation status, as it had not been affected by fire for 40 years. This stand was defined as our reference site (longitude: $-23.64^{\circ}$; latitude: $\left.-64.59^{\circ}\right)$. The second stand, of approximately 1000 ha, was located near our reference site, and was affected by a fire in 2013. This stand was designated as our closeburned site (longitude: $-23.69^{\circ}$; latitude: $-64.58^{\circ}$ ). The third stand, of about 1000 ha, was located $3.4 \mathrm{~km}$ away from our reference site and was affected by the same fire as the close-burned site in 2013. It was defined as our distant-burned site (longitude: $-23.66^{\circ}$; latitude: $-64.55^{\circ}$ ).

\section{Bird assemblages}

On each site, we delimited an area of about 100 ha and established 30 bird point counts of $50 \mathrm{~m}$ radius separated by at least $150 \mathrm{~m}$ from one another (Ralph et al. 1996; Malizia et al. 2005). From December 2015 to August 2017, we recorded bird presence twice per year at each counting point: during the bird reproductive season (October to March), and during the nonreproductive season (April to September). At each point count, we registered all birds seen or heard for $10 \mathrm{~min}$ between dawn and 1000 hours (Malizia et al. 2005). We did not record birds during heavy rains or strong winds. We also did not include birds associated with wetlands, nor those that were passing through the point count. Birds were identified according to the South American Classification Committee (Remsen et al. 2018).

We determined bird abundance by counting individuals of all bird species recorded at each point count, and then calculated the mean and standard deviation of the abundance per site. Based on Stotz et al. (1996), and Blendinger and Álvarez (2009), we grouped bird species according to the type of environment they lived in (AM, 
birds of disturbed sites; BBS, birds of forest edges or secondary environments; and BM, birds of mature forests; Additional file 1). We calculated the mean and standard deviation of the abundance of each bird group per site. We determined differences in abundance among sites, and bird groups within each site, by running General Linear Models (GLM), using the glm.nb function of the MASS statistical package (Venables and Ripley 2002), and then doing Tukey multi-comparisons with multcomp statistical package (Hothorn et al. 2008). For the GLM of birds grouped by environment, we treated the total abundance of the surveys as a compensatory variable (offset). To compare abundance among sites, we also drew bar figures with ggplot2 (Wickham 2016) and lattice (Sarkar 2008) packages. To analyze bird diversity at each site, we drew re-refraction-extrapolation curves with the iNEXT package, developed for species richness (Hill number: order 0). We determined equitativity with Shannon exponential entropy (order 1), and species dominance through the inverse of Simpson (order 2), with 95\% confidence intervals (Jost 2006; Chao et al. 2014). We also identified bird species that were exclusive to each site. We determined similarities in structure and composition of bird communities among sites with nonmetric multidimensional scaling (NMDS), run with the vegan package (Clarke and Warwick 2001; Oksanen et al. 2018). We evaluated bird assemblage similarities by running a multivariate nonparametric analysis of variance (PERMANOVA), adjusting distance matrices to a linear model (ADONIS function of vegan package; Anderson 2001; Oksanen et al. 2018). For NMDS and PERMANOVA analyses, we used quantitative (based on abundance and on the Bray-Curtis index) and qualitative data (based on species richness and on the Jaccard index) (Clarke and Warwick 2001). Stress of 2dimensional plots was measured by Kruskal's stress formula I and the Spearman rank correlation was calculated in order to point out which sites were more correlated to NMDS axes (Clarke and Warwick 2001). To ordinate NMDS, we performed Hellinger transformations in the matrix of bird species to reduce the weight of more abundant species in the analysis (Legendre and Gallagher 2001).

\section{Forest structure variables}

For characterizing the forest structure of the three sites, we established $500 \mathrm{~m}^{2}$ concentric circular plots at every bird point count (Husch et al. 2003). Within these plots, we measured total height and diameter at breast height (dbh), $1.3 \mathrm{~m}$ above the ground, of each tree, and noted whether they were dead or alive. These measurements were taken for trees with $\mathrm{dbh}>10 \mathrm{~cm}$ (Husch et al. 2003). We estimated the percentage of canopy cover with a densiometer at 12 points in each plot, located 4 , 8 , and $12 \mathrm{~m}$ from the center, in the direction of each cardinal point (Bullock 1996; Newton 2007). We also determined the visibility of the horizon through the understory up to $2 \mathrm{~m}$ from the ground. To do this we placed a $2 \mathrm{~m}$ tall stick, marked every $20 \mathrm{~cm}, 10 \mathrm{~m}$ from the plot center in the direction of each cardinal point. We registered the number of marks seen on the stick in each direction (Higgins et al. 1996). For each site, we calculated mean and standard deviation of number of trees per hectare, basal area $\left(\mathrm{m}^{2} \mathrm{ha}^{-1}\right)$, dbh $(\mathrm{cm})$, and height of live and standing dead (snag) trees (m), as well as percent (\%) of canopy cover and percent (\%) of understory visibility. We analyzed structural differences between live and dead trees (snags) among sites with the KruskalWallis and Tukey tests using the DescTools package (Signorell et al. 2018).

\section{Relationships between bird assemblage and forest structural variables}

We explored the relationship between bird assemblage and forest structural variables by running Canonic Correspondence Analysis (CCA) with the vegan package. We also performed a graphic analysis with the ggord package (Marcus 2017). The CCA presents an inertia component that could be analogically interpreted as the variance of data sets. The proportion of variation explained by bird species, partial components of the inertia, was computed with the inertcomp function provided by the vegan package (Oksanen et al. 2018). Previous to running the CCA, we centered and standardized vegetation variables with the caret package (Kuhn et al. 2016) and determined if they were correlated to the corrplot package (Wei and Simko 2017). To ordinate the CCA, we performed Hellinger transformations in the matrix of bird species (Legendre and Gallagher 2001).

\section{Results \\ Bird assemblages}

Abundance and richness of all bird species was lower in the unburned reference site. There was no difference between the close-burned and distant-burned sites (Figs. 1 and 2). Bird diversity was higher at the close-burned site than at the other two sites (Fig. 2). At both burned sites, species richness and diversity of birds typical of disturbed environments were higher than at the reference site (Fig. 2). Abundance of birds typical of disturbed environments was higher at the distant-burned site than at the other two (Fig. 1). Abundance and richness of bird species typical of forest edges or secondary environments were higher at the distant burned site (Figs. 1 and 2). Bird assemblages in distant-burned and reference sites showed the least similarity, considering both quantitative data (abundance) and qualitative data (species richness) (Fig. 3). Only 5\% of the bird species were 


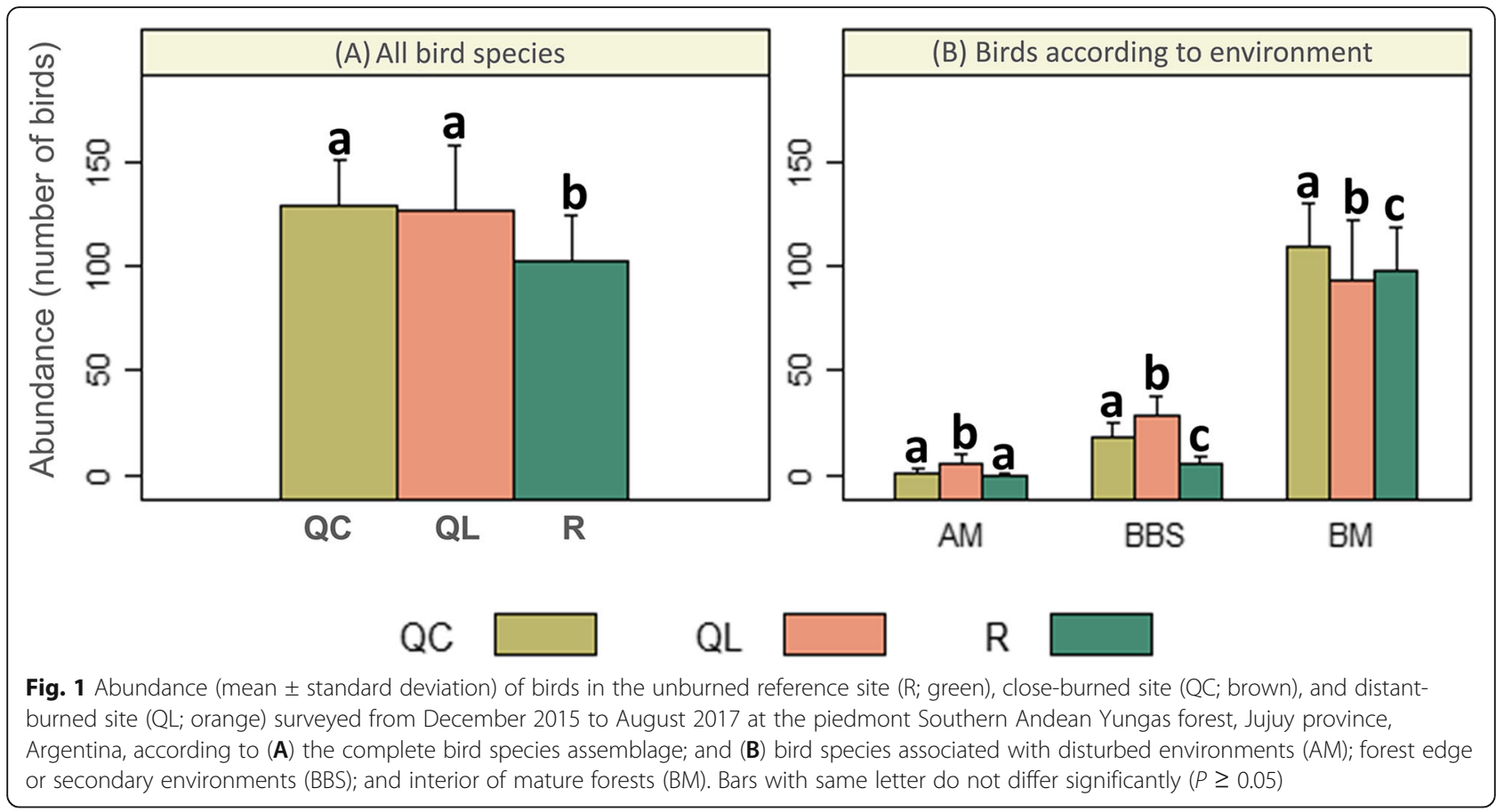

exclusive to the reference site, $6 \%$ to the close-burned site, and $14 \%$ to the distant-burned site (Additional file 1).

\section{Structural variables}

As expected, structural variables (dbh, basal area, mean height, density) of live trees, canopy cover, and understory vegetation visibility were different among the three sites, being greater for those with more trees (reference site $>$ close-burned site $>$ distant-burned site), except for tree height, which did not differ between the reference site and close-burned site (Table 1). Snag structural variables were lower for the reference site than the close- and distant-burned sites (Table 1).

\section{Relationship between bird assemblage and forest structural variables}

Diameter at breast height and density of snags and live trees were highly correlated $(r>0.7)$ with other variables, and were not included in the CCA (Additional file 2). We found a relationship between bird assemblage and forest structural variables (inertia $=0.34 ; P=0.001$ ). High values in visibility of the understory vegetation, canopy cover, basal area, and height of live trees were highly associated with bird assemblages at the reference site $(P<0.05$; Fig. 4). High values in tree height and basal area of snags were highly associated with bird assemblages at burned sites $(P<0.05$; Fig. 4). The bird species Myiothlypis bivitta Zimmer was highly associated with the reference site, while Saltator coerulescens Vieillot, Coryphospingus cucullatus Müller, and Phacellodomus rufifrons Wied were associated with the distant-burned site (Fig. 4).

\section{Discussion}

This is the first study evaluating the influence of forest fires on bird assemblages at the piedmont of the Southern Andean Yungas in Northwest Argentina. The higher bird species richness at post-fire sites can be explained by the presence of bird species typical of mature unburned forests and the addition of species associated with disturbed, edge, or secondary forests (Banks et al. 2010). In a study conducted on semi-arid shrublands at the Murray Mallee region in southeastern Australia, Watson et al. (2012) found that up to five years after fire, species richness was higher at nearby unburned vegetation patches, but these differences disappeared after ten years. The burned sites included in our study have greater bird variety than in unburned vegetation. These results, different from Watson's results, may be related to the dissimilitude between forest structure and dynamics, as well as habitat requirements of the bird species inhabiting both continents.

The difference in bird species composition at burned sites may be a consequence of the proximity to the unburned site, since birds from unburned forests tend to recolonize burned places (Law et al. 2018). The high similarity in bird species found between reference and close-burned sites might be due to the higher number of bird species belonging to mature forests that inhabit both sites. The presence of birds associated with forest edges or secondary environments at the distant-burned site can explain the difference we found between burned sites in terms of bird assemblages. Differences in bird assemblages among sites appear to be more related to the 


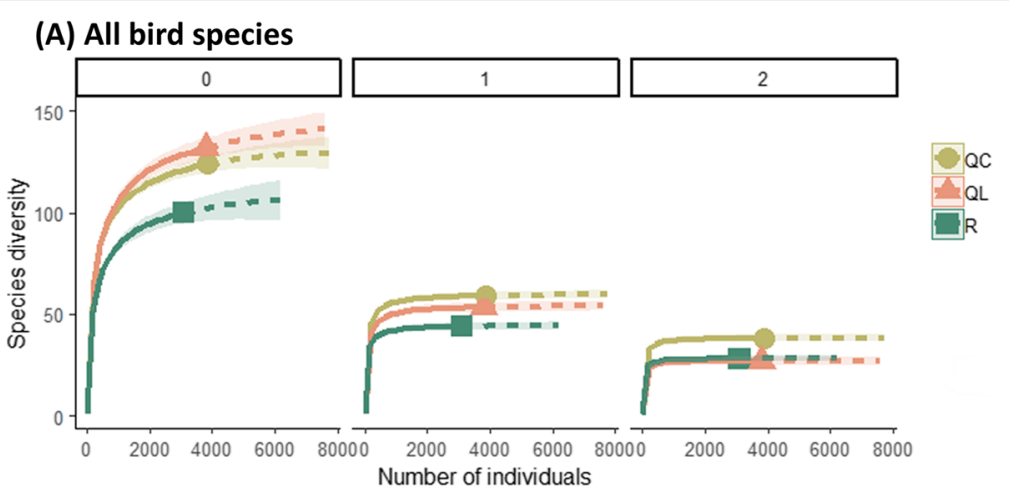

\section{(B) Bird species associated with mature forest}

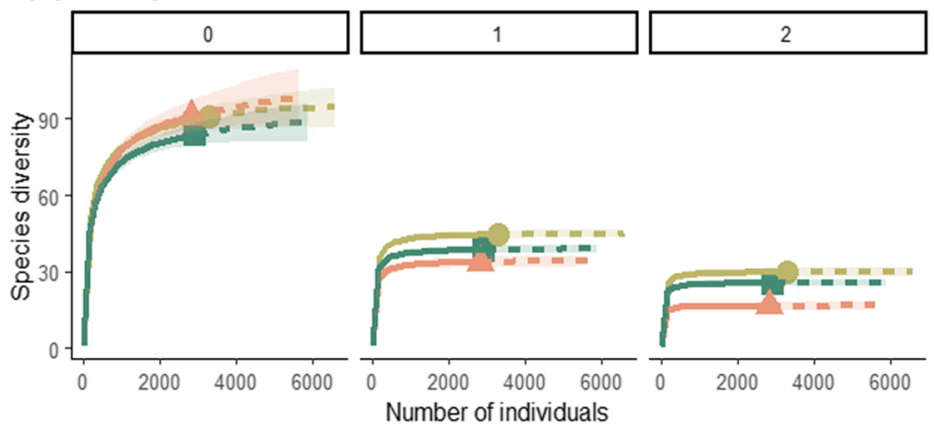

(C) Bird species associated with edge environment

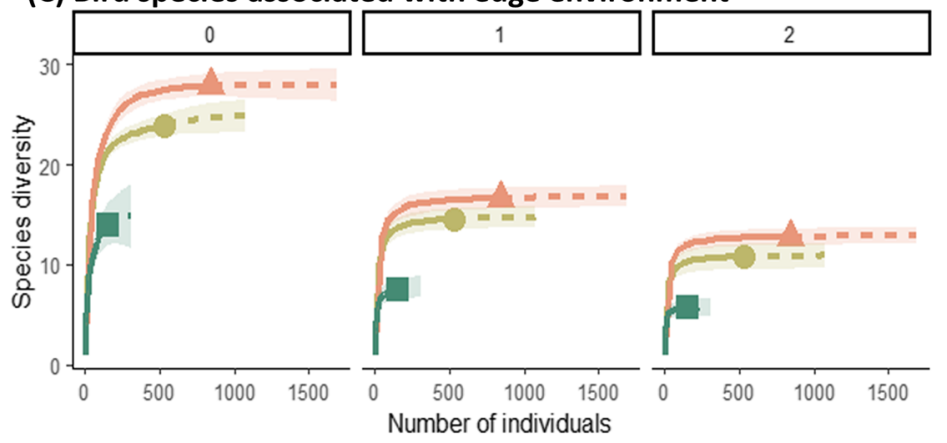

(D) Bird species associated with disturbed environment

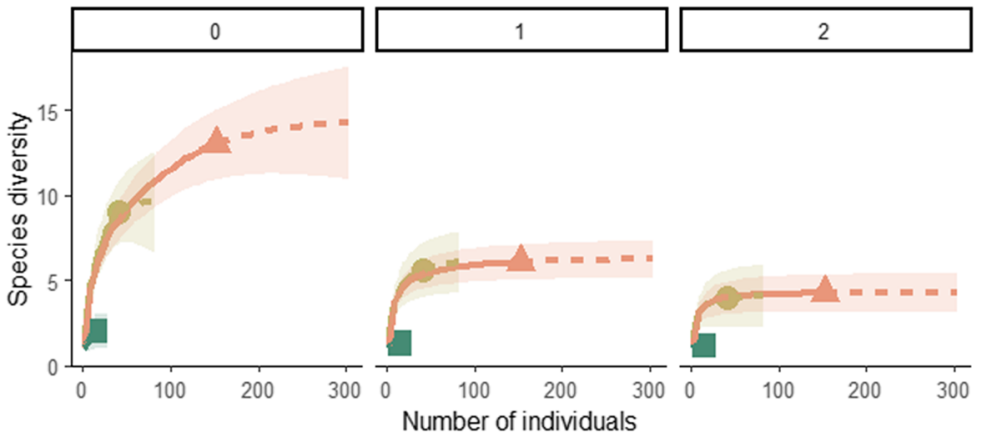

Fig. 2 Rarefaction species curves of diversity values (number of species) for (A) all bird species, (B) birds associated with mature forest, (C) birds associated with edge or secondary environments, and (D) birds associated with disturbed environments in the unburned reference site (R; green), close-burned site (QC; brown), and distant-burned site (QL; orange), as recorded in surveys from December 2015 to August 2017 at the piedmont Southern Andean Yungas forest, Jujuy province, Argentina. Curves under the 0 represent diversity values for Hill numbers, under the 1 for species richness, and under the 2 for the exponential of Shannon entropy. Solid lines represent interpolation from data, dotted lines extrapolation from data, and shaded areas represent the $95 \%$ confidence intervals. Confidence intervals that overlap do not show significant difference $(P>0.05)$ 


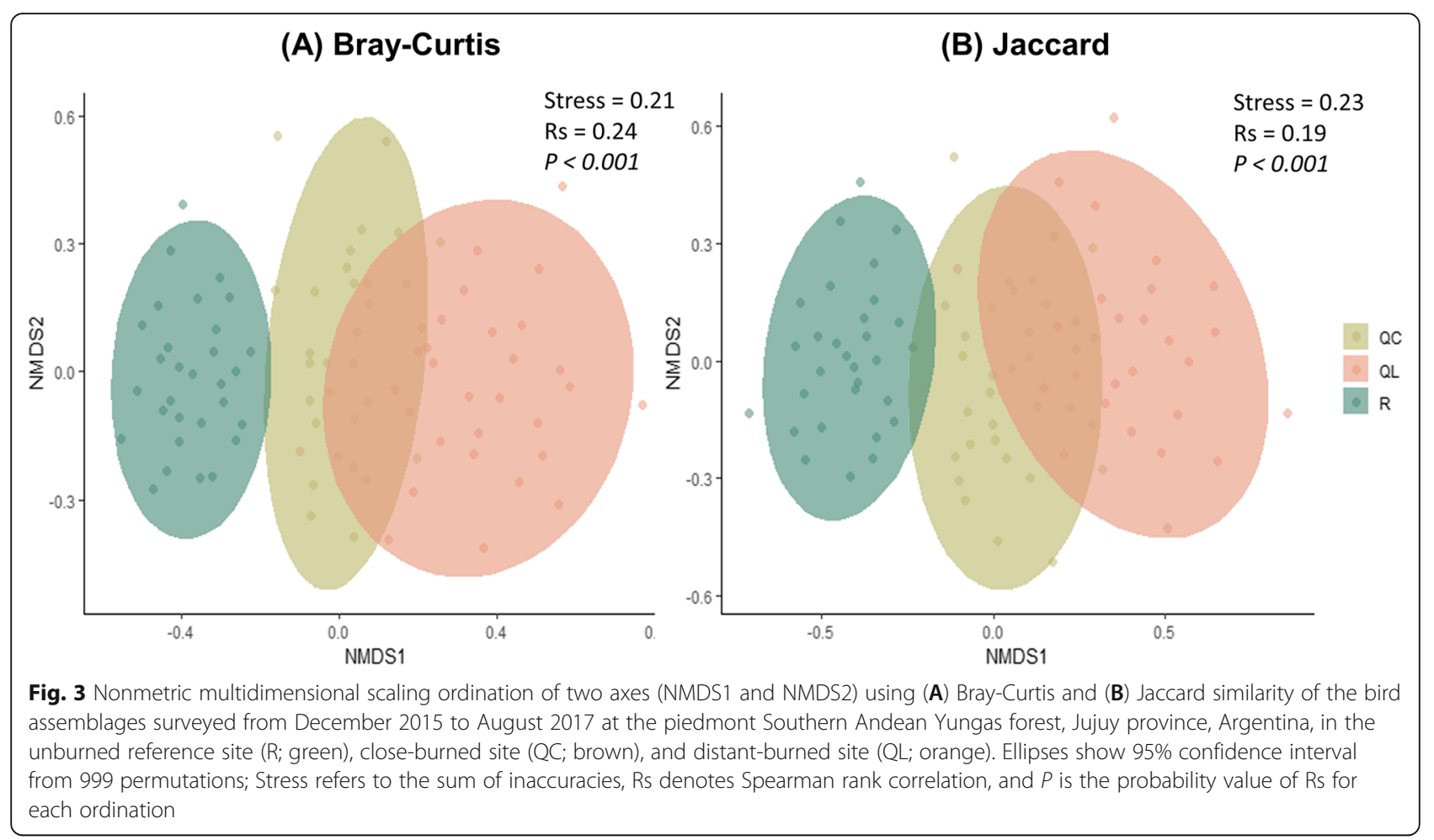

distance between the unburned and burned sites, rather than to the influence of the fire itself, as other authors have also pointed out (Hutto 1995, 2008; Nappi et al. 2003; Koivula and Schmiegelow 2007). The association of bird assemblages with forest structure has been mentioned in similar studies (Pearson 1993; Díaz et al. 2005; Fontaine et al. 2009). Birds inhabiting the reference site were associated with basal area and height of live trees, whereas birds inhabiting the more distant burned site were closely related to basal area and height of snags.
Birds inhabiting the close-burned site, however, were related to number of live trees and high number of snags. Snags play an important ecological role for different bird species (Saab et al. 2009). Woodpeckers (Picidae, Vigors) excavate cavities in the trunks of snags for refuge or nesting, while other bird species use dead branches for perching (Politi et al. 2010). In the Southern Andean Yungas of Argentina, fire patches and their distance to undisturbed forest are important factors in conservation of bird diversity, at least during the first post-fire

Table 1 Forest structural variables (diameter at breast height [dbh], basal area, height, and density) of live and standing dead (snags) trees, canopy cover, and understory visibility (Under vis) at the unburned reference site (R), close-burned site (QC), and distant-burned site (QL), measured between December 2015 to August 2017 at the piedmont Southern Andean Yungas forest, Jujuy province, Argentina. Values indicate mean \pm standard deviation; same letter $(a, b, c)$ next to the values denotes no significant difference $(P \geq 0.05)$

\begin{tabular}{|c|c|c|c|c|c|c|c|c|c|c|c|c|c|}
\hline Forest attribute & Variable & $\mathrm{R}$ & & & & QC & & & & QL & & & \\
\hline \multirow[t]{4}{*}{ Live trees } & $\mathrm{dbh}(\mathrm{cm})$ & 33 & \pm & 13 & a & 17 & \pm & 9 & $b$ & 5 & \pm & 11 & c \\
\hline & basal area $\left(\mathrm{m}^{2} \mathrm{ha}^{-1}\right)$ & 10 & \pm & 7 & a & 2 & \pm & 3 & $b$ & 0 & \pm & 2 & c \\
\hline & height (m) & 14 & \pm & 4 & a & 14 & \pm & 8 & a & 3 & \pm & 8 & $\mathrm{~b}$ \\
\hline & density (individuals ha ${ }^{-1}$ ) & 86 & \pm & 39 & a & 64 & \pm & 63 & $b$ & 8 & \pm & 19 & c \\
\hline \multirow[t]{4}{*}{ Snags } & $\mathrm{dbh}(\mathrm{cm})$ & 2 & \pm & 6 & a & 17 & \pm & 7 & $b$ & 16 & \pm & 8 & $\mathrm{~b}$ \\
\hline & basal area $\left(\mathrm{m}^{2} \mathrm{ha}^{-1}\right)$ & 0 & \pm & 0 & a & 2 & \pm & 1 & $b$ & 3 & \pm & 3 & $b$ \\
\hline & height (m) & 1 & \pm & 3 & a & 13 & \pm & 7 & $\mathrm{~b}$ & 12 & \pm & 6 & $\mathrm{~b}$ \\
\hline & density (individuals ha ${ }^{-1}$ ) & 1 & \pm & 5 & a & 70 & \pm & 69 & $b$ & 90 & \pm & 66 & $\mathrm{~b}$ \\
\hline Canopy cover (\%) & & 51 & \pm & 12 & a & 31 & \pm & 14 & $b$ & 17 & \pm & 8 & c \\
\hline Under vis (\%) & & 87 & \pm & 12 & $\mathrm{a}$ & 54 & \pm & 21 & $b$ & 16 & \pm & 13 & c \\
\hline
\end{tabular}




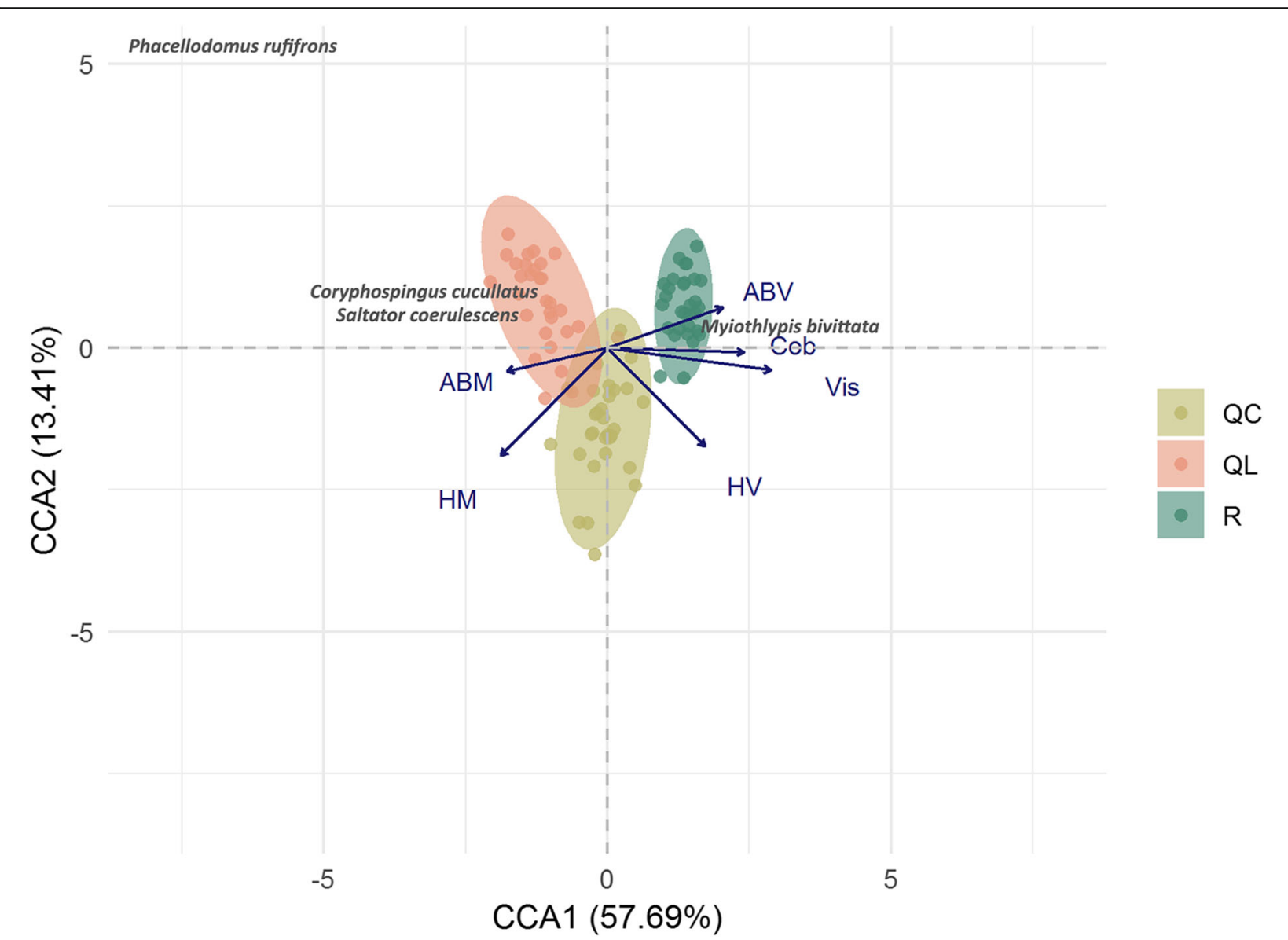

Fig. 4 Representation of the first two axes (CCA1 and CCA2) of the canonical correspondence analysis (CCA) of the bird assemblages with the forest structural variables surveyed from December 2015 to August 2017 at the piedmont Southern Andean Yungas forest, Jujuy province, Argentina, in the unburned reference site (R; green), close-burned site (QC; brown), and distant-burned site (QL; orange). Shown in parentheses after each axis is the percent of variability contribution of that axis. Blue arrows indicate the direction of the strength of the forest structural variables: $A B M=$ basal area of standing dead trees (snags), AltM = height of standing dead trees (snags), ABV = basal area of live trees, AltV = height of live trees, Cob = canopy cover, and Vis = understory visibility. Bird species strongly associated with each axis are shown. Resolution of this image remains poor

successional stages ( $<5$ yr after fire). The high proportion of bird species typical of unburned forests found at the three study sites can indicate that they all provide the refuge that Southern Andean Yungas birds need after fire. Thus, a patchy burned environment close to unburned forest may facilitate bird recolonization of mature forests (Mayhew et al. 2019), while at the same time providing habitat for other bird species as post-fire succession proceeds. Forest managers and policy makers should carefully consider these aspects, since within the current era of climate change, different models predict an increasing incidence of wildfires in neotropical forests in the near future (Scholze et al. 2006).

\section{Conclusions}

In the Southern Andean Yungas forests of Northwest Argentina, fire-disturbed patches and their distance to undisturbed forest are important factors in bird assemblage conservation. Bird assemblage abundance and richness was higher at burned sites, and differences in bird assemblages increased with distance to unburned patches. The high proportion of bird species characteristic of undisturbed forest in the three sites indicated, however, that they collectively constitute a substantial refuge for Southern Andean Yungas forest birds. Maintenance of continuous, unburned forests patches during the first successional stages after fires $(<5 \mathrm{yr})$ may help bird assemblages to recover quickly. This is because, as the distance from unburned forest increases (as in the distant-burned site), bird assemblage characteristics of fire-disturbed or secondary forests increase, and may delay the recovery process of those typical of undisturbed forests. Lack of connectivity and fragmentation, due mainly to man-caused fires and timber extraction, and the threat of climate change, are the main problems compromising sustainability of Southern Andean Yungas 
forests in Argentina. Two key aspects should be considered to help preserve bird assemblages: (1) restrict the use of fire to increase forest connectivity and reduce fragmentation; and (2) promote selective timber logging and ban post-fire snag removal to assure the recovery of habitat for bird assemblages. These recommendations could be extrapolated to other ecosystems sharing similar structures and functions.

\section{Supplementary information}

Supplementary information accompanies this paper at https://doi.org/10 1186/s42408-020-00074-0.

Additional file 1. Bird species, grouped by family, recorded $(X)$ in the unburned reference site, close-burned site, and distant-burned site surveyed from December 2015 to August 2017 at the piedmont Southern Andean Yungas forest, Jujuy province, Argentina. Environment with which each species was associated is shown as: $\mathrm{AM}=$ disturbed environments; $\mathrm{BBS}=$ forest edge or secondary environments; and $\mathrm{BM}=$ interior mature forests. Asterisk $\left(^{*}\right)$ indicates that the bird species is exclusive to the site.

Additional file 2. Correlation values for forest structural variables measured from December 2015 to August 2017 at the piedmont Southern Andean Yungas forest, Jujuy province, Argentina. Forest structural variables: DAPM = diameter at breast height of standing dead trees (snags); DenM = density of snags; $\mathrm{ABM}=$ basal area of snags; $\mathrm{HM}=$ height of snags; DAPV = diameter at breast height of live trees; DenV = density of live trees; $A B V$ : basal area of live trees; $H V=$ height of live trees; $\mathrm{Cob}=$ canopy cover; Vis $=$ understory visibility. In the color ramp, dark red indicates a high negative correlation, white indicates no correlation, and dark blue indicates a high positive correlation.

\section{Acknowledgements}

We would like to acknowledge the Argentinean Northwest Region of the Administration of National Parks of Argentina, the Secretary of Environment of Jujuy province, and M. Ulivarry and A. Blanco of Ledesma Corporation, for allowing installation of all treatments on their lands. We are also grateful for the fire information provided by the technical branch of the National Fire Management Service in Jujuy. We also acknowledge the Foundation for Conserving and Studying Biodiversity (www.cebio.org.ar) for their support during our fieldwork. Our recognition also goes to the park rangers of Calilegua National Park, especially to R. Terán, for his unconditional support during field trips. Special thanks go to S. Alcalde, Y. Tejerina, M. Odetti, J. Di Tomaso, and all others who collaborated during field samplings, and also to N. González Baffa Trasci and M. Figueroa for their advice in the statistical analyses of this study.

\section{Authors' contributions}

M. Morales: study design, data collection, analyses, and manuscript writing; C. Vivanco: data collection and manuscript revision; G. Defossé, N. Politi, and L.O. Rivera: study design, manuscript writing and revision. All authors read and approved the final manuscript.

\section{Funding}

Field study was carried out within the frame of the Argentine National Agency for Promotion of Science and Technology (Grant PICT 2012-0892), and with grants from the Argentine National Research Council (CONICET PIP 112-201201-00259, and PIO 1402014100133), and from Jujuy National University (SECTER A0176).

\section{Availability of data and materials}

The datasets generated or analyzed during the current study are not publicly available but are available from the corresponding author on reasonable request.

Ethics approval and consent to participate Not applicable.
Consent for publication

Not applicable.

\section{Competing interests}

The authors declare that they have no competing interests.

\section{Author details}

${ }^{1}$ Instituto de Ecorregiones Andinas, Universidad Nacional de Jujuy - Consejo Nacional de Investigaciones Científicas y Técnicas, Alberdi 47, 4600 San Salvador de Jujuy, Jujuy, Argentina. ${ }^{2}$ Centro de Investigación Esquel de Montaña y Estepa Patagónica (CIEMEP), Universidad Nacional de la Patagonia San Juan Bosco - Consejo Nacional de Investigaciones Científicas y Técnicas, Roca 780, 9200 Esquel, Chubut, Argentina.

Received: 9 September 2019 Accepted: 24 April 2020

Published online: 24 June 2020

\section{References}

Agee, J.K. 1993. Fire ecology of Pacific Northwest forests, 493. Washington, D.C.: Island Press.

Anderson, M.J. 2001. A new method for non-parametric multivariate analysis of variance. Austral Ecology 26: 32-46 https://doi.org/10.1111/j.1442-9993.2001. 01070.pp.x.

Arias, M., and A.R. Bianchi. 1996. Estadísticas climatológicas de la provincia de Salta, 189. Salta: EEA Salta. Dirección de Medio Ambiente y Recursos Naturales, Gobierno de Salta.

Banks, S.C., M. Dujardin, L. Mcburney, D. Blair, M. Barker, and D.B. Lindenmayer. 2010. Starting points for small mammal population recovery after wildfire: recolonization or residual populations? Oikos. 120: 26-37. https://doi.org/10. 1111/j.1600-0706.2010.18765.x

Blendinger, P.G., and M.E. Álvarez. 2009. Aves de la Selva Pedemontana de las Yungas australes. In Selva Pedemontana de las Yungas: historia natural, ecología y manejo de un ecosistema en peligro, ed. A.D. Brown, P.G. Blendinger, T. Lomáscolo, and P. García Bes, 233-272. Tucumán: Ediciones del Subtrópico.

Brown, A.D., P.G. Blendinger, T. Lomáscolo, and P. García. 2009. Selva pedemontana de las Yungas. In Historia natural, ecología y manejo de un ecosistema en peligro, 487. Yerba Buena: Ediciones del Subtrópico.

Brown, A.D., and L. Malizia. 2004. Las selvas Pedemontanas de las Yungas en el umbral de la extinción. Ciencia Hoy. 14: 53-63.

Bullock, J. 1996. Plants. In Ecological census techniques, ed. W.J. Sutherland, $111-$ 138. Cambridge: Cambridge University Press.

Cabrera, A.L. 1994. Regiones Fitogeograficas Argentinas. In Enciclopedia Argentina de Agricultura y Jardinería, 85. Buenos Aires: Tomo II. Editorial ACME S.A.C.I.

Cabrera, A.L., and A. Willink. 1973. Biogeografía de América Latina. In Monografía 13, Serie de Biología. Washington, DC: Organización de Estados Americanos.

Chao, A., C.H. Chiu, and L. Jost. 2014. Unifying species diversity, phylogenetic diversity, functional diversity, and related similarity and differentiation measures through Hill numbers. Annual Review of Ecology, Evolution, and Systematics 45: 297-324. https://doi.org/10.1146/annurev-ecolsys-120213091540.

Clarke, K., and R. Warwick. 2001. Change in marine communities: An approach to statistical analysis and interpretation, 82. Plymouth: PRIMER-E Ltd.

Díaz, I., J.J. Armesto, S. Reid, K.E. Sieving, and M.F. Willson. 2005. Linking forest structure and composition: Avian diversity in successional forests of Chiloé Island, Chile. Biological Conservation 123: 91-101. https://doi.org/10.1016/j. biocon.2004.10.011.

Flannigan, M., B. Stocks, M. Turetsky, and W. Wotton. 2009. Impacts of climate change on fire activity and fire management in the circumboreal forest. Global Change Biology 15: 549-560 https://doi.org/10.1111/j.1365-2486.2008. 01660.x.

Fontaine, J.B., D.C. Donato, W.D. Robinson, B.E. Law, and J.B. Kauffman. 2009. Bird communities following high-severity fire: Response to single and repeat fires in a mixed-evergreen forest, Oregon, USA. Forest Ecology and Management 257: 1496-1504. https://doi.org/10.1016/j.foreco.2008.12.030.

Higgins, K.F., J.L. Oldemeyer, K.J. Jenkins, G.K. Clambey, and R.F. Harlow. 1996. Vegetation sampling and measurement. In Research and Management Techniques for Wildlife and Habitats, ed. T.A. Bookhout, 567-591. Lawrence: The Wildlife Society, Allen Press, Inc. 
Hothorn, T., F. Bretz, P. Westfall, and R.M. Heiberger. 2008. multcomp: Simultaneous Inference in General Parametric Models. Biometrical Journal 50: 346-363. https://doi.org/10.1002/bimj.200810425.

Husch, B., T.W. Beers, and J.A. Kershaw. 2003. Forest mensuration, 443. New York: Wiley.

Hutto, R.L. 1995. Composition of bird communities following stand-replacement fires in northern rocky-mountain (USA) conifer forests. Conservation Biology 9 : 1041-1058. https://doi.org/10.1046/j.1523-1739.1995.9051033.x-i1.

Hutto, R.L. 2008. The ecological importance of severe wildfires: some like it hot. Ecological Applications 18: 1827-1834 https://doi.org/10.1890/08-0895.1.

Jost, L. 2006. Entropy and diversity. Oikos 113: 363-375 https://doi.org/10.1111/j. 2006.0030-1299.14714.x.

Koivula, M.J., and F.K.A. Schmiegelow. 2007. Boreal woodpecker assemblages inrecently burned forested landscapes in Alberta, Canada: effects of post-fire harvesting and burn severity. Forest Ecology and Management 242: 606-618. https://doi.org/10.1016/j.foreco.2007.01.075.

Kuhn, M., J. Wing, S. Weston, A. Williams, C. Keefer, A. Engelhardt, T. Cooper, et al. 2016. Caret: Classification and Regression Training. https://cran.r-project.org/ web/packages/caret/index.html. Accessed 15 Feb 2019.

Law, B., A. Doty, M. Chidel, and T. Brassil. 2018. Bat activity before and after a severe wildfire in Pilliga forests: Resilience influenced by fire extent and landscape mobility? Austral Ecology 43 (6): 706-718. https://doi.org/10.1111/ aec.12617.

Legendre, P., and E. Gallagher. 2001. Ecologically meaningful transformations for ordination of species data. Oecología. 129 (2): 271-280. https://doi.org/10. 1007/s004420100716

Lomáscolo, T., A.D. Brown, and L.R. Malizia. 2010. Reserva de biosfera de las Yungas. Ed. Del Subtrópico, 168 p.

Malizia, L.R., P.G. Blendinger, M.E. Alvarez, L.O. Rivera, N. Politi, and G. Nicolossi. 2005. Bird assemblages in andean premontane Forests of northwestern argentina. Ornitologia Neotropical. 16: 231-251.

Marcus, W.B. 2017. ggord: Ordination Plots with ggplot2. https://zenodo.org/ badge/latestdoi/35334615. Accessed 10 Feb 2019

Martinuzzi, S., L. Rivera, N. Politi, B. Bateman, E. Ruiz De Los Llanos, L. Lizarraga, and V. Radeloff. 2017. Enhancing biodiversity conservation in existing landuse plans with widely available datasets and spatial analysis techniques. Environmental Conservation 45: 1-9. https://doi.org/10.1017/ S0376892917000455.

Mayhew, R.J., J.A. Tobias, L. Bunnefeld, and D.H. Dent. 2019. Connectivity with primary forest determines the value of secondary tropical forests for bird conservation. Biotropica. 51 (2): 219-233. https://doi.org/10.1111/btp.12629.

Nappi, A., P. Drapeau, J.F. Girouz, and J.F.L. Savard. 2003. Snag use by foraging black-backed woodpeckers (Picoides arcticus) in a recently burned eastern boreal forest. Auk. 120: 505-511. https://doi.org/10.2307/4090203.

Newton, A.C. 2007. Forest Ecology and Conservation: a handbook of techniques. 1st ed, 454. Oxford: Oxford University Press.

Oksanen, J., F.G. Blanchet, M. Friendly, R. Kindt, P. Legendre, D. Mcglinn, P.R. Minchin, R.B. O'Hara, G.L. Simpson, P. Solymos, M.H.H. Stevens, E. Szoecs, H. Wagner. 2018. Community Ecology Package. https://CRAN.R-project.org/ package=vegan. Accessed 15 Feb 2019.

Oyarzabal, M., J. Clavijo, L. Oakley, F. Biganzoli, P. Tognetti, I. Barberis, H.M. Maturo, R. Aragón, P. Campanello, D. Prado, M. Oesterheld, and R.J.C. León. 2018. Unidades de Vegetación de la Argentina. Ecología Austral 28: 40-63. https:// doi.org/10.25260/EA.18.28.1.0.399.

Pearson, S.M. 1993. The spatial extent and relative influence of landscape-level factors on wintering bird populations. Landscape Ecology 8: 3-18. https://doi. org/10.1007/BF00129863.

Pidgeon, A.M., L.O. Rivera, S. Martinuzzi, N. Politi, and B. Bateman. 2015. Will representation targets based on area protect critical resources for the conservation of the Tucuman Parrot? Cooper Ornithological Society, The Condor. 117: 503-517. https://doi.org/10.1650/CONDOR-14-214.1.

Politi, N., M. Hunter Jr., and L.O. Rivera. 2010. Availability of cavities for avian cavity nesters in selectively logged subtropical montane forests of the Andes. Forest Ecology and Management 260: 893-906. https://doi.org/10.1016/j. foreco.2010.06.009.

Ponce Calderón, L., B. Aguilar Valdéz, D. Rodríguez Trejo, E. López Pérez, and J. Santillá Pérez. 2012. Influencia del fuego sobre la riqueza y diversidad de aves en un Bosque Templado en Puebla. Revista Mexicana de Ciencias Forestales. 3 (10): 65-76. https://doi.org/10.29298/rmcf.v3i10.526.
Prado, D., R. Pennington, and C. Pendry. 2000. Neotropical seasonally dry forests and Quaternary vegetation changes. Journal of Biogeography 27: 261-273. https://doi.org/10.1046/j.1365-2699.2000.00397.x.

Ralph, C.J., G.R. Geupel, P. Pyle, T.E. Martin, D.F. De Sante, and B. Milá. 1996. Manual de métodos de campo para el monitoreo de aves terrestres, 46. Albany: Gen. Tech. Rep., CA: Pacific Southwest Research Station, Forest Service. U.S. Department of Agriculture. https://doi.org/10.2737/PSW-GTR-159.

Remsen, J.V., J.I. Jr., Areta, C.D. Cadena, S. Claramunt, A. Jaramillo, J.F. Pacheco, J. Pérez-Emon, M.B. Robbins, F.G. Stiles, D.F. Stotz, K.J. Zimmer. 2018. A classification of the bird species of South America. American Ornithologists' Union. http://www.museum.lsu.edu/. Accessed 15 Apr 2019.

Saab, V.A., R.E. Russell, and J.G. Dudley. 2009. Nest-site selection by cavity-nesting birds in relation to postfire salvage logging. Forest Ecology and Management 257 (1): 151-159. https://doi.org/10.1016/j.foreco.2008.08.028.

Sarkar, D. 2008. Lattice: Multivariate data visualization with $R, 280$. New York: Springer. https://doi.org/10.1007/978-0-387-75969-2.

Scholze, M., W. Knorr, N.W. Arnell, and I.C. Prentice. 2006. A climate-change risk analysis for world ecosystems. Proceedings of the National Academy of Sciences of the United States of America 103: 13116-13120 https://doi.org/10. 1073/pnas.0601816103.

Signorell, A., et al. 2018. DescTools: Tools for descriptive statistics. https://cran.rproject.org/package=DescTools. Accessed 12 Feb 2019.

Sodhi, N.S., Ç.H. Sekercioglu, J. Barlow, and S.K. Robinson. 2011. Conservation of tropical birds, 312. Chichester: Wiley-Blackwell. https://doi.org/10.1002/ 9781444342611.

Stotz, D.F. J.W. Fitzpatrick, T.A. Parker III, and D.K. Moskovits. 1996. Neotropical Birds: Ecology and Conservation, 312. Chicago: University of Chicago Press.

Venables, W.N., and R.D. Ripley. 2002. Modern Applied Statistics with S. In 4th ed, 498 p. New York: Springer. https://doi.org/10.1007/978-0-387-21706-2.

Watson, S.J., R.S. Taylor, D.G. Nimmo, L.T. Kelly, M.F. Clarke, and A.F. Bennett. 2012 The influence of unburned patches and distance from refuges on post-fire bird communities. Animal Conservation 15 (5): 499-507. https://doi.org/10. 1111/j.1469-1795.2012.00542.x

Wei, T., and V. Simko. 2017. R package "corrplot": Visualization of a Correlation Matrix (Version 0.84). https://github.com/taiyun/corrplot. Accessed 11 Feb 2019.

Wickham, H. 2016. ggplot2. Elegant graphics for data analysis, 213. New York: Springer-Verlag. https://doi.org/10.1007/978-3-319-24277-4_9.

\section{Publisher's Note}

Springer Nature remains neutral with regard to jurisdictional claims in published maps and institutional affiliations.

\section{Submit your manuscript to a SpringerOpen ${ }^{\circ}$ journal and benefit from:}

- Convenient online submission

- Rigorous peer review

- Open access: articles freely available online

High visibility within the field

- Retaining the copyright to your article

Submit your next manuscript at $>$ springeropen.com 